\title{
Erratum to: Determinability of Perception as Homogeneity of Representation
}

\author{
Víctor M. Verdejo ${ }^{1}$
}

Published online: 31 July 2017

(C) Springer Science+Business Media B.V. 2017

\section{Erratum to: Rev.Phil.Psych. \\ DOI 10.1007/s13164-017-0338-3.}

In this article the following Acknowledgement section was inadvertently left out:

\begin{abstract}
Acknowledgements An earlier draft of this paper was presented at the Institute of Philosophy (University of London, UK) in March 2016. I am grateful to the audience for a very useful discussion, and especially to Marie Guillot and Marcus Giaquinto. This research has been supported by the Secretary for Universities and Research of the Department of Economy and Knowledge (Government of Catalonia) and the Ministry of Economy and Competitiveness (Government of Spain) and the European Union through the research projects FFI2016-80588-R and FFI2015-63892-P (MINECO, AEI/ FEDER, EU).
\end{abstract}

We regret any inconvenience this may have caused.

The online version of the original article can be found under doi:10.1007/s13164-017-0338-3

Víctor M. Verdejo

vm.verdejo@gmail.com

1 Departament de Lògica, Història i Filosofía de la Ciència, Universitat de Barcelona, Barcelona, Spain 